\title{
Spatial distribution and ecological niche modelling of Triplochiton scleroxylon K. Schum., in the Guineo-Congolese region of Benin (West Africa)
}

\author{
Ismaïla TOKO IMOROU
}

\author{
Laboratory of Cartography (LaCarto), University of Abomey-Calavi, 10 BP 1082 Cotonou-Houéyiho, Benin. \\ E-mail: ismael_toko@yahoo.fr; tokismael@gmail.com
}

\begin{abstract}
Triplochiton sleroxylon (samba) is a West and Central African forest species of high socio-economic value which is increasingly threatened by anthropogenic pressures from various sources. The aim of this study was to determine the impact of climate change on the spatial distribution of Triplochiton sleroxylon in the Guineo-Congolese region of Benin. All of 2311 occurrence data of this species were combined with current and future climate variables in the Maxent program under RCP scenarios 4.5 and 8.5 by 2055 . Analysis of the spatial pattern of Triplochiton scleroxylon revealed an aggregative distribution between $1 \mathrm{~m}$ and $7 \mathrm{~m}$ distance. But for a distance between 0 and $1 \mathrm{~m}$ and more than $7 \mathrm{~m}$, the spatial pattern revealed a random spatial distribution. Under current climatic conditions, $45.17 \%$ of the study area of the Guineo-Congolese region in Benin and $61.69 \%$ of the one of protected areas are currently very suitable for the cultivation and conservation of samba. Projections to 2055 indicate a significant increase in the area of these habitats for the two scenarios used. These results show that the current and future climatic conditions of the Guineo-Congolese region in Benin remain favourable for the cultivation and conservation of this species. Unfortunately, outside protected areas, these favourable habitats are occupied by settlements and fields. Taking these results into account could effectively contribute to the sustainable conservation of this species in Benin.
\end{abstract}

(C) 2020 International Formulae Group. All rights reserved.

Keywords: Climate change, Maxent program, niche modelling, aggregative distribution, Triplochiton scleroxylon, Benin.

\section{INTRODUCTION}

Africa's natural resources in general and those of West Africa in particular are undergoing noticeable changes at both local and regional levels (Orekan et al., 2010). The changing trend in land cover dynamics in recent decades has been characterized by a considerable decline in the area of natural plant communities in favour of anthropogenic ones (Orekan et al., 2010; Arouna, 2012; Toko Imorou et al., 2017; Folahan, 2018; Diouf et al., 2019). Benin, like other West
African countries, is also experiencing serious degradation of its forest resources. According to OSFACO's land mapping results in Benin, deforestation and net degradation are estimated at $2.1 \%$ and $0.6 \%$ respectively between 2005 and 2015 (Toko Imorou et al., 2019). This decline results from the current spatial pattern prevailing in Benin in general and especially in the southern part of the country, where almost half of the country's population is located (INSAE, 2013). This situation has led to the fragmentation of the 
natural habitats to several animal and plant species in their containment area. Among these species, we have Triplochiton scleroxylon commonly referred to as samba (Nketiah et al., 1998). Triplochiton scleroxylon is widely distributed in the forest area of West and Central Africa from Guinea to the Central African Republic, and southwards to Gabon and the Democratic Republic of Congo. The wood of this species is widely used in carpentry in the manufacture of hives, as an energy source, in sculpture, but is vulnerable to insect attack (Vidal et al., 2006; Adedeji et al., 2014; Krawczyk-Szulc et al., 2014; Oluoti et al., 2016). According to Kamga (2019), Triplochiton scleroxylon reduced to dust is a promising and effective biosorbent for the reduction of paraquat from aqueous solutions and for the treatment of industrial wastewater.

The leaves of this species are used in the traditional medicine in Ivory Coast and Benin as boiled vegetables or as sauces (Vroh et al., 2014). Bark is used to cover roofs and walls with boxes, and in traditional medicine to treat oedema, varicella and as an analgesic (Vroh et al., 2014). This ethnobotanical importance is the source of strong anthropogenic pressure which threatens the survival of this species in the study area as everywhere else. In Ghana, Triplochiton scleroxylon is considered vulnerable and vegetative propagation techniques have been developed for the species to overcome seed supply difficulties and encourage reforestation efforts (Nketiah et al., 1998).

Apart from anthropogenic factors of various origins that threaten the survival of species, the impacts of climate change could compromise their integrity in their natural habitats (GIEC, 2013). This was illustrated by several authors (Phillips et al., 2006; Fandohan et al., 2015; Platts et al., 2015) over the range of the species. In Benin and more particularly in the Guineo-Congolese region which represents the containment area of Triplochiton scleroxylon, few studies have been carried out on the species. Among these studies, none has focused on the potential impact of climate change on the distribution of habitats of this species. Therefore, this study aims to fill the gap in order to determine the impact of climate change on the spatial distribution of Triplochiton sleroxylon in the Guineo-Congolese region of Benin.

\section{MATERIALS AND METHODS \\ Study area}

The Guineo-Congolese region extends over six provinces and is located in the southern part of Benin. The climate is subequatorial with a bimodal rainfall regime that includes four seasons: two rainy seasons and two dry seasons (Neuenschwander, 2011). The average annual rainfall varies between 900 and $1300 \mathrm{~mm}$ between 1986 and 2017 (ASECNA, 2018). The dominant soils are ferrallitic. Natural vegetation exists only in the form of small islands of dense forest. This region includes four phytogeographical districts (Adomou, 2005): Coastal, Pobè, Ouémé Valley and Plateau (Figure 1). It accounts for $50.4 \%$ of Benin's total population in 2013 (INSAE, 2013).

\section{Species description}

Triplochiton scleroxylon commonly referred to as samba or obeche or African whitewood, is found in the semi-deciduous moist forest, in the transition zone between forest and moist savannah, and in scattered outliers where local topography favours a closed forest community. It is also frequent in drier and more disturbed types of forest. Triplochiton scleroxylon is frequent around dwellings. Trees occur naturally from Guinea to Democratic Republic of Congo and from Gabon to Nigeria. Throughout its natural range, there is always a marked dry period between December and April. Triplochiton scleroxylon is referred to as a pioneer species, and it has been suggested that shifting cultivation in West Africa has influenced the natural distribution. Trees normally occur in clusters of 10 or more and isolated trees are very rare (Nketiah et al., 1998; Akoegninou et al., 2006; Orwa et al., 2009). In Benin, Triplochiton scleroxylon is found in the phytodistricts of Pobè, Plateau, Zou, Ouémé 
valley, Bassila. It is listed on the International Union for Conservation of Nature (IUCN) red list as an endangered species in Benin (Adomou et al., 2011).

\section{Data collection \\ Spatial distribution pattern}

The spatial structure of Triplochiton scleroxylon was studied on a $200 \mathrm{~m} \times 200 \mathrm{~m}$ site based on Ripley (1977) method. This method helped to characterize the spatial structure of a seedling (aggregation, regularity or randomness) simultaneously for several distances.

\section{Occurrence data of Triplochiton scleroxylon}

Occurrence data of Triplochiton scleroxylon were collected by global positioning system (GPS) in the GuineoCongolese region of Benin between 2016 and 2018. These data were combined with those downloaded from GBIF's (global biodiversity information facility) website (http://www.gbif.org/occurrence/download) in 2019. In total, 2311 occurrence data of Triplochiton scleroxylon were collected (including 291 for field work and 2020 from GBIF). Figure 2 shows the spatialization of the occurrence data used.

\section{Environmental variables}

The data on current climate conditions are from the climate data in the WorldClim version 1.4 database. For future climate projections, the database "AFRICLIM 3.0: high resolution ensemble climate projections forAfrica"(https://webfiles.york.ac.uk/KITE/A friClim) was used with a total of 21 variables (Table 1) under two scenarios: RCP 4.5 and RCP 8.5 by 2055 (Platts et al., 2015). The climatic layers used are those of 30 -second arc resolution (i.e. a resolution grid of approximately $1 \mathrm{~km} \times 1 \mathrm{~km}$ ). The database developed was subjected to correlation analysis with ENMTools 1.3 to eliminate highly correlated variables (Elith et al., 2010).

\section{Data analysis \\ Spatial distribution pattern}

The pair correlation function (pcf) of $\mathrm{g}(\mathrm{r})$ (Stoyan, 1987) of the spatstat package helped to determine whether the model of the spatial structure of the individuals of the species was random, aggregated or regular; the spatial scales at which these patterns occurred. The basic assumption is that the spatial structure of individuals of Triplochoton scleroxylon is random. When the curve $\mathrm{g}(\mathrm{r})$ is outside the upper or lower confidence envelopes for a given distance $r$, the null hypothesis has been rejected at this distance.

The significance of the observed spatial structure model deviating from the expected distribution under the basic assumption (totally random spatial structure) was evaluated by comparing the observed distribution function with the confidence interval generated by 500 Monte Carlo simulations under the null hypothesis. All spatial analyzes were performed in R 3.6.1 ( $\mathrm{R}$ Core Team, 2019). The function $g$ (r) has the formula:

$g_{\mathrm{i} . \mathrm{j}}(r)=\frac{K_{i . \mathrm{j}}^{\prime}(r)}{(2 \pi r)}$

With $K_{i . \mathrm{j}}^{\prime}(r)$, the derivative of the function $K_{i . \mathrm{j}}(r)$ Ripley (1991) from a point sowing at a distance $\mathrm{r}$.

$g_{\mathrm{i}}(r)=1$ indicates a random character, whereas $g_{\mathrm{i}}(r)>1$ indicates the aggregation and the curve $\mathrm{g}_{\mathrm{i}}(\mathrm{r})$ is above the confidence interval (upper envelope). Moreover, $g_{\mathrm{i}}(r)<$ 1 indicate the regularity and the curve $\mathrm{g}_{\mathrm{i}}(\mathrm{r})$ is below the confidence interval (lower envelope).

\section{Modelling and evaluation of the model}

The Maximum Entropy (Maxent) approach (Philips et al., 2006) was used to model areas potentially favourable to Triplochiton scleroxylon under current and future climatic conditions. Some of the occurrence data $(25 \%)$ was used to test the prediction model and the second part containing $75 \%$ of the occurrence data was used to calibrate it into five replicates by cross-validation. The performance of the model was assessed by statistics from Area Under the Curve (AUC) (Phillips et al., 2006) and True Skill Statistics (TSS) (Allouche et al., 2006). 


\section{Mapping of modelling results}

The modelling results were imported into ArcGIS 10.3 software for mapping the extent of the species' habitats under current and future climatic conditions. The gross probability distribution obtained by the model was considered as a measure of the probability of occurrence of the species. A three-level categorization of this probability was made for the discrimination of the species' habitats. Thus, in this study, any habitat with a probability of occurrence of the species of less than 0.5 is considered as unfavourable habitat. If this probability is between 0.5 and 0.7 , the habitat is said to be moderately favourable. Probability values greater than or equal to 0.7 are considered very favourable habitats.

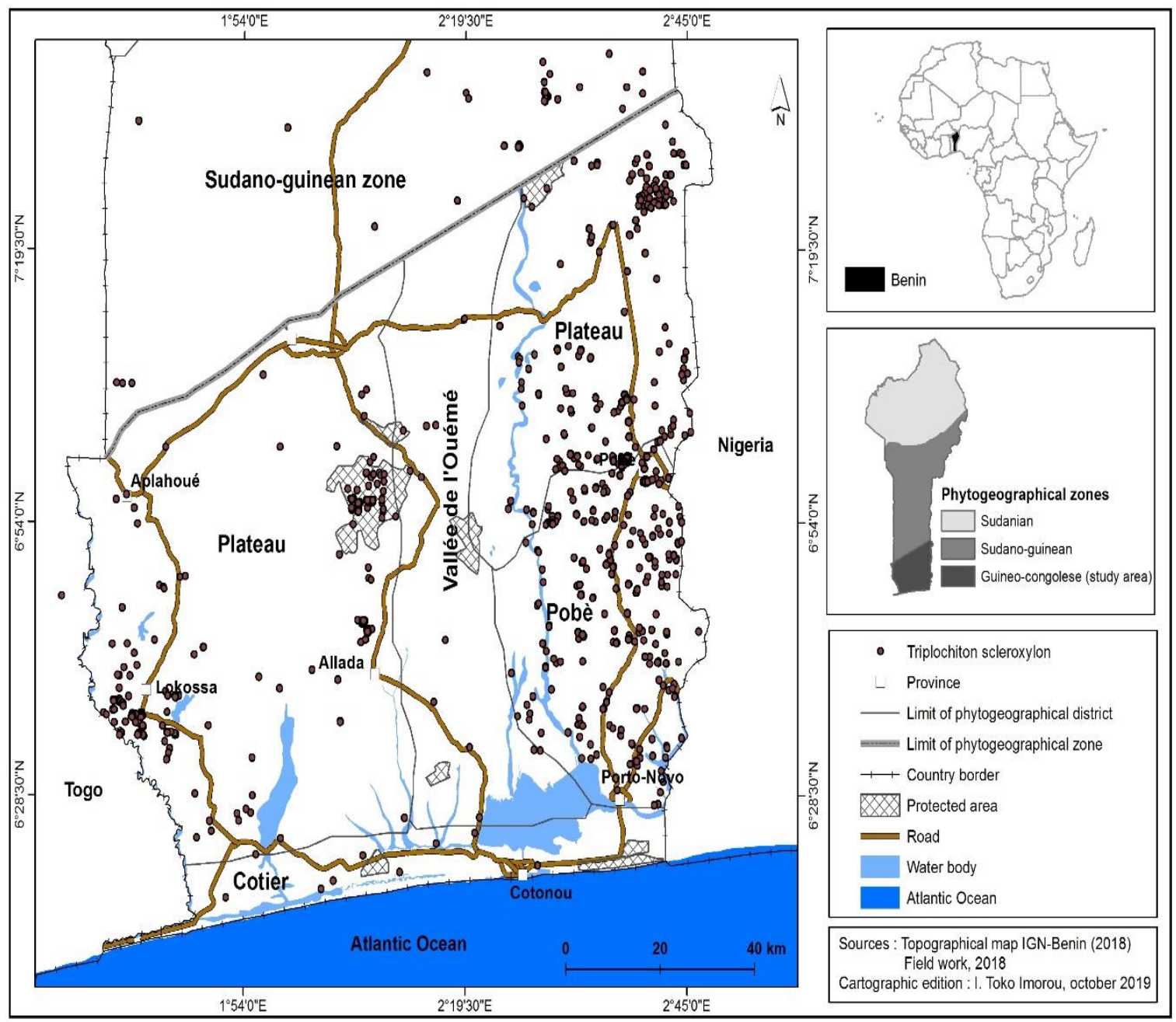

Figure 1: Localization of the study area. 


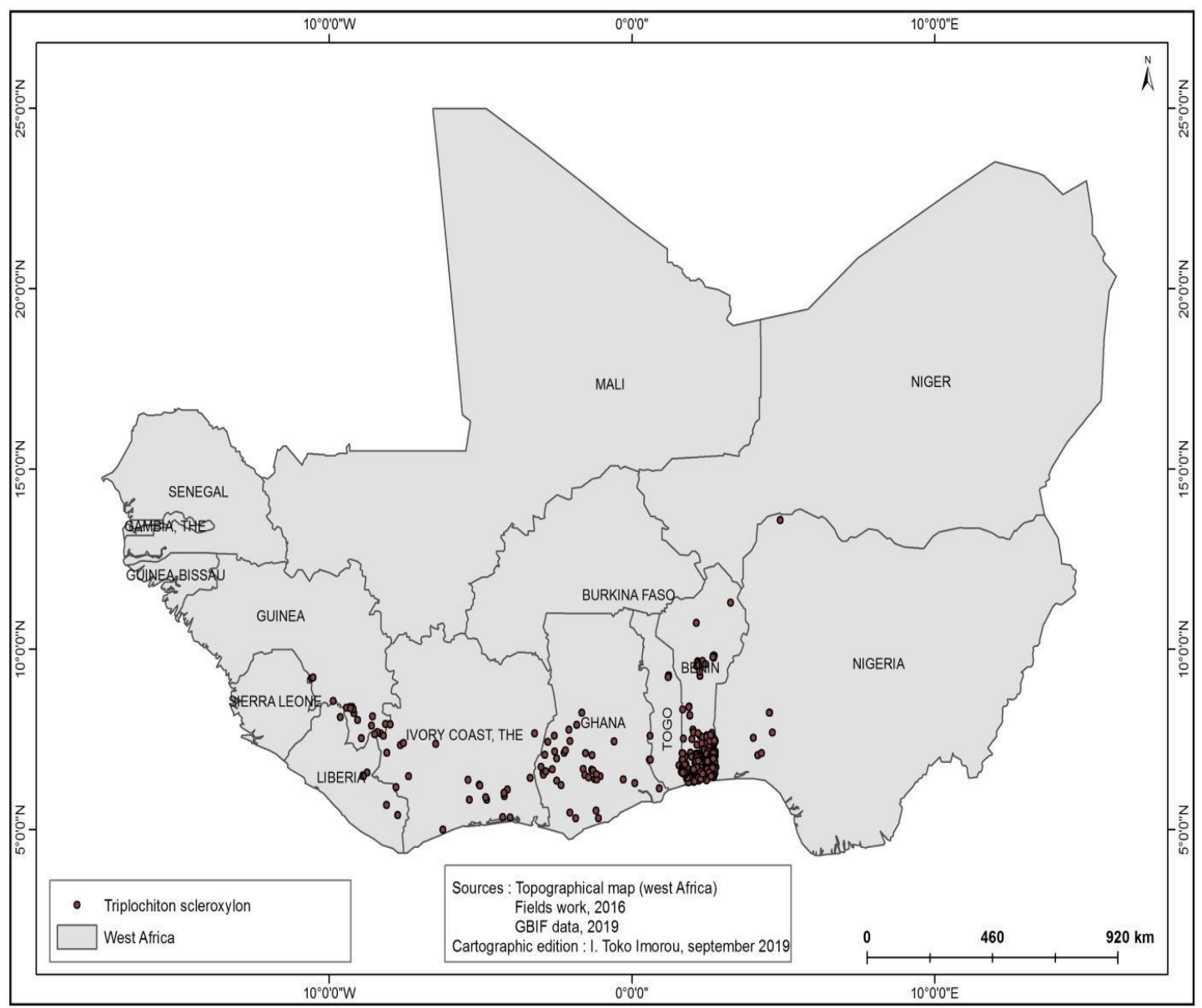

Figure 2: Spatialization of the occurrence data used.

Table 1: List of 21 bioclimatic variables used.

\begin{tabular}{|c|c|c|}
\hline Variables & Climatic parameters & Units \\
\hline \multicolumn{3}{|c|}{ Temperature (tbio) } \\
\hline [BIO1] & Mean annual temperature [1] & $(\mathrm{C} \times 10$, Int16) \\
\hline [BIO2] & Mean diurnal range in temp [2] & (C x10, Int16) \\
\hline [BIO3] & Isothermality [3] & $(\mathrm{C} \times 10$, Int16) \\
\hline [BIO4] & Temperature Seasonality [4] & $(\mathrm{C} \times 10$, Int16) \\
\hline [BIO5] & Max temp warmest month & $(\mathrm{C} \times 10$, Int 16) \\
\hline [BIO6] & Min temp coolest month & $(\mathrm{C} \times 10$, Int16) \\
\hline [BIO7] & Annual temperature range [5] & $(\mathrm{C} \times 10$, Int 16) \\
\hline [BIO10] & Mean temp warmest quarter [6] & $(\mathrm{C} \times 10$, Int16) \\
\hline [BIO11] & Mean temp coolest quarter [6] & (C x10, Int16) \\
\hline
\end{tabular}




\begin{tabular}{|c|c|c|}
\hline [PET] & Potential evapotranspiration [7] & $(\mathrm{mm}$, UInt16) \\
\hline \multicolumn{3}{|c|}{ Moisture (mbio) } \\
\hline [BIO12] & Mean annual rainfall [8] & (mm, UInt16) \\
\hline [BIO13] & Rainfall wettest month & (mm, UInt16) \\
\hline [BIO14] & Rainfall driest month & (mm, UInt16) \\
\hline [BIO15] & Rainfall seasonality [4] & (mm, UInt16) \\
\hline [BIO16] & Rainfall wettest quarter [6] & (mm, UInt16) \\
\hline [BIO17] & Rainfall driest quarter [6] & $(\mathrm{mm}, \mathrm{UInt} 16)$ \\
\hline$[\mathrm{MI}]$ & Annual moisture index [9] & (x100, UInt16) \\
\hline [MIMQ] & Moisture index moist quarter [6] & $(x 100$, UInt16) \\
\hline [MIAQ] & Moisture index arid quarter [6] & $(x 100$, UInt16) \\
\hline$[\mathrm{DM}]$ & Number of dry months [10] & (months, Byte) \\
\hline [LLDS] & Length of longest dry season [11] & (months, Byte) \\
\hline
\end{tabular}

Sources: Africlim and World clim version 1.4 database, 2019.

\section{RESULTS}

\section{Spatial distribution of Triplochiton scleroxylon}

Figure 3 shows the spatial structure of Triplochiton scleroxylon.

For a distance between 0 and $1 \mathrm{~m}$ and more than $7 \mathrm{~m}$, the curve $\mathrm{g}(\mathrm{r})$ is located between the upper and lower confidence envelopes (Figure 3). This indicates a random spatial structure. On the other hand, the aggregative spatial structure is observed between 1 and $7 \mathrm{~m}$. Globally, Triplochiton scleroxylon exhibits a random spatial structure on the study area.

\section{Contribution of the variables to predict the ecological niche}

Table 2 presents the contribution of the variables to predict Triplochiton scleroxylon habitats.

Isothermality (bio 3) is the variable that contributed most to the prediction of Triplochiton scleroxylon habitats in terms of the contribution and importance of permutation (Table 2). It is followed by the minimum temperature of the coldest month (bio 6) then by the seasonality of the temperature (bio 4) through its contribution and the importance of the permutation of the average annual precipitation (bio 12). Variables such as bio 7 and bio 15 contributed little to the prediction of Triplochiton scleroxylon habitats.

\section{Predictive power of the model}

The average True Skill Statistics (TSS) value obtained is 0.63 with a standard deviation of 0.005 . The AUC evaluation criterion is 0.960 with a standard deviation of 0.004 showing that the model used predicts better than chance. On the other hand, it is stable between rehearsals. These values indicate the good performance of the model in predicting the spatial and temporal dynamics of Triplochiton scleroxylon habitats in the study area. Figure 4 shows the area calculator below the receiver curve.

$\begin{aligned} & \text { Dynamics of current and future } \\ & \text { distribution areas of Triplochiton } \\ & \text { scleroxylon }\end{aligned}$
The current and future distribution
areas of Triplochiton scleroxylon have varied
in space and time depending on the scenarios
used. Table 3 shows the variation in the area
of current and future Triplochiton scleroxylon


habitats and figure 5 shows the spatialization of these habitats.

Under current climatic conditions, the habitats more favourable to the distribution of Triplochiton scleroxylon represent an area of $6011 \mathrm{~km}^{2}(45.18 \%)$. These habitats are located in the north, east, central and part of the southwest of the Guineo-Congolese region in Benin (Figure 5). The moderately favourable ones cover an area of $4609 \mathrm{~km}^{2}(34.64 \%)$ of the study area and are located from northeast to southeast, central and part of the north. The unfavourable habitats cover an area of 2686 $\mathrm{km}^{2}(20.19 \%)$ and are mainly located in the extreme south and from the centre to the northwest of the region.
As part of the mitigation of greenhouse gas emissions ( $\mathrm{RCP} 4.5$ ), more favourable habitats will experience a $33.80 \%$ increase in the area currently very favourable to them. This increase is in the order of $1.04 \%$ for those who are moderately favourable. On the other hand, unfavourable habitats will experience a significant decrease $(77.44 \%)$ in their current area (Figure 5).

As part of an increase in greenhouse gas emissions (RCP 8.5), the proportion of currently very favourable habitats will increase by $44.56 \%$ by 2055 (Table 3 ). On the other hand, those who are moderately favourable and unfavourable will experience a decrease of $16.58 \%$ and $78.07 \%$ in their current area respectively.

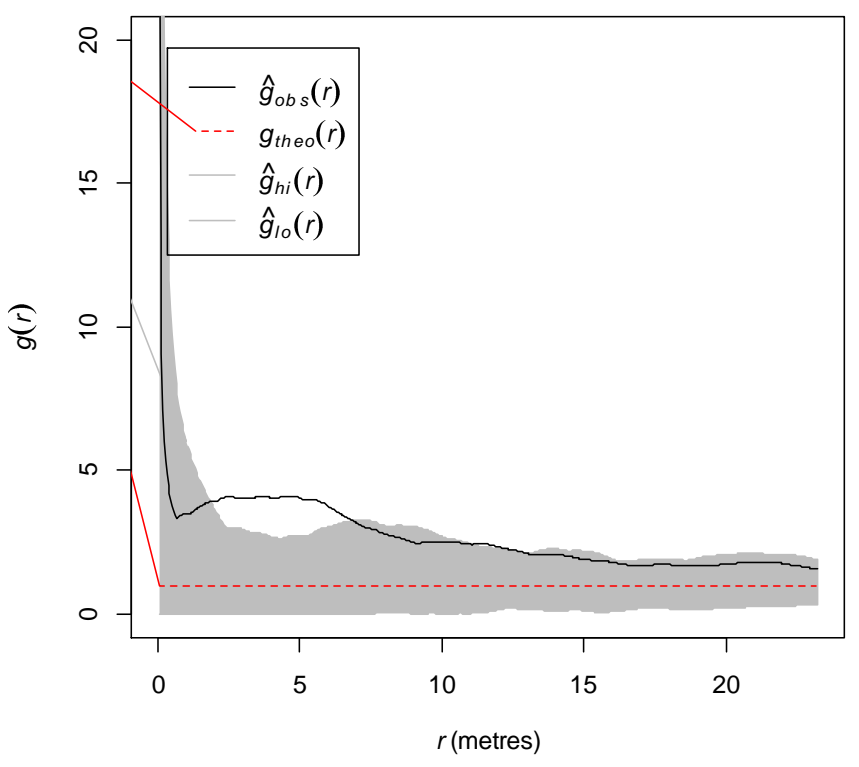

Figure 3: Spatial structure of Triplochiton scleroxylon.

Table 2: Contribution of variables to habitats prediction.

\begin{tabular}{ccc}
\hline Variables & Contribution (\%) & Importance of permutation (\%) \\
\hline bio3 & 51,2 & 72,3 \\
bio6 & 21,8 & 8,9 \\
bio4 & 11 & 2,9 \\
bio12 & 9,9 & 9,9 \\
bio7 & 4,4 & 2 \\
bio15 & 1,6 & 4 \\
\hline
\end{tabular}

Sources: Africlim and World clim version 1.4 database, 2019. 


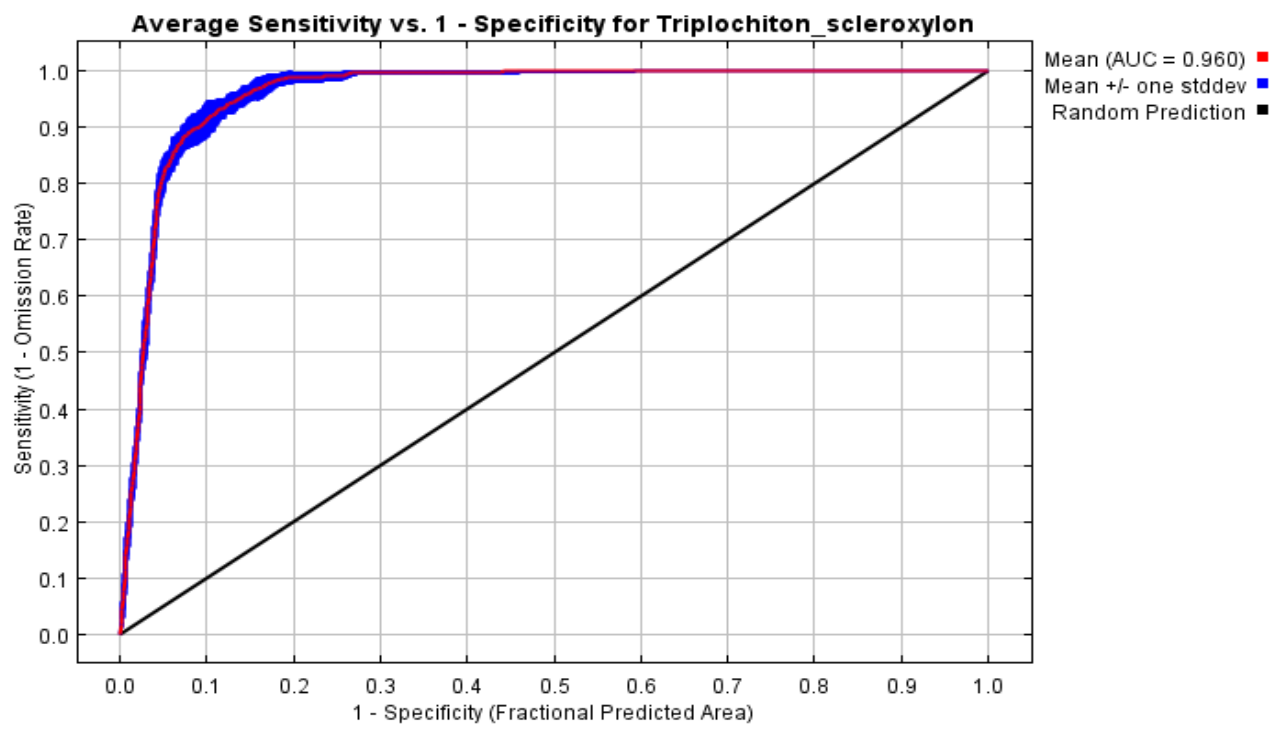

Figure 4: Calculator of area below the receiver curve.

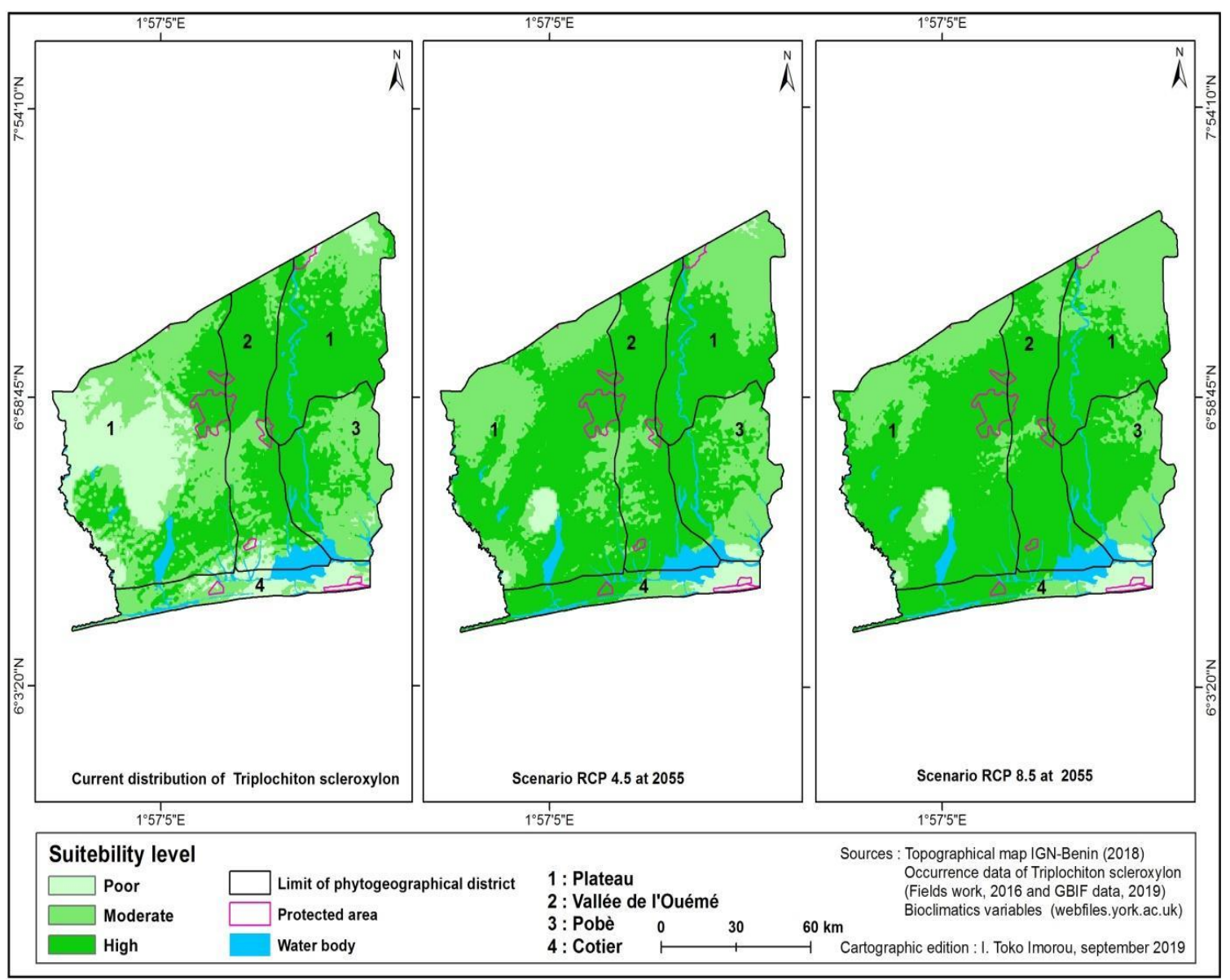

Figure 5: Spatialization of Triplochiton scleroxylon habitats. 
Table 3: Current and future distribution areas in the Guineo-Congolese region.

\begin{tabular}{ccccccc}
\hline $\begin{array}{c}\text { Triplochiton } \\
\text { scleroxylon }\end{array}$ & \multicolumn{2}{c}{$\begin{array}{c}\text { Most favorable } \\
\text { habitats }\end{array}$} & \multicolumn{2}{c}{$\begin{array}{c}\text { Moderately favourable } \\
\text { habitats }\end{array}$} & \multicolumn{2}{c}{$\begin{array}{c}\text { Less favorable } \\
\text { habitats }\end{array}$} \\
\hline & $\begin{array}{c}\text { Area } \\
\left(\mathbf{K m}^{2}\right)\end{array}$ & $\begin{array}{c}\text { Proportion } \\
\mathbf{( \% )}\end{array}$ & $\begin{array}{c}\text { Area } \\
\left(\mathbf{K m}^{2}\right)\end{array}$ & $\begin{array}{c}\text { Proportion } \\
\mathbf{( \% )}\end{array}$ & $\begin{array}{c}\text { Area } \\
\left(\mathbf{K m}^{2}\right)\end{array}$ & $\begin{array}{c}\text { Proportion } \\
(\boldsymbol{\%})\end{array}$ \\
\cline { 2 - 7 } Present & 6011 & - & 4609 & - & 2686 & - \\
RCP 4.5 & 8043 & 33.80 & 4657 & 1.04 & 606 & -77.44 \\
RCP 8.5 & 8870 & 47.56 & 3845 & -16.58 & 589 & -78.07 \\
\hline Sources: Field data, 2018 and GBIF data, 2019. & & & & &
\end{tabular}

\section{DISCUSSION}

\section{Spatial distribution}

Analysis of the spatial pattern of Triplochiton scleroxylon revealed an aggregative distribution between $1 \mathrm{~m}$ and $7 \mathrm{~m}$ distance. But for a distance between 0 and $1 \mathrm{~m}$ and more than $7 \mathrm{~m}$, the spatial pattern revealed a random spatial distribution. The Triplochiton scleroxylon morphological structure characterized by dense and rounded crown, with thick branches and the dispersal mode of seeds which was anemochore may explained this spatial distribution. The observed distribution could also be attributed to the various interactions between this plant species and their environment (competition, predation) and human disturbance. The similar results were obtained by Kiki (2005), Dohou (2006) and Goussanou et al. (2017) in Wari-Maro forest reserve and Zouzounkan forest in Benin, using the same spatial distribution method on Isoberlinia doka and Isoberlinia tomentosa. These studies revealed that distribution of individuals of Isoberlinia doka and Isoberlinia tomentosa was aggregative in short distance but presented sparse aggregates after large distances. Goussanou et al. (2017) explained the spatial distribution pattern of Isoberlinia doka and Isoberlinia tomentosa by the seeds dispersal mode which are ballochore. In fact, ripe seeds were released under mother-trees involving their concentration at short distance and thus the aggregation at short distance.

According to several authors (Goreaud, 2000; Dungan, 2002; Jesel, 2005; Kiki, 2005; Dohou, 2006; Toko Imorou, 2013; Karimou, 2015; Goussanou et al., 2017; Salako et al., 2018), the spatial distribution pattern of species can be explained by several factors including the maximum distance observed between the nearest neighbors, the mode of dispersion of the diaspores and especially the human disturbed. The results of study done by Salako et al. (2018) revealed that in natural undisturbed stands such as those found in protected areas, the Borassus aethiopum spatial pattern is often controlled by complex interactions of several ecological factors (e.g. water availability, soil fertility and patchiness, termite mounds, dispersal activities, and density-dependent and distancedependent mortality). However, in human disturbed landscapes such as farmlands, this pattern could be altered. Thus, the local environment of an individual strongly influences its dynamics.

In addition, several authors (Goreaud, 2000; Dungan, 2002; Karimou, 2015) emphasize that the characterization of a spatial distribution depends on the scale of observation. Indeed, the spatial extent or scale could influence the observation of the spatial distribution of the species according to whether it is small or large. A species may 
therefore have an aggregated distribution at large scale or extent, while by decreasing the study area, the distribution model changes.

\section{Ecological niche modelling}

The modelling of the distribution of potential Triplochiton scleroxylon habitats was carried out using the Maxent (Maximum Entropy) program. This program uses an optimization procedure comparing the presence of the species with the characteristics of the environment based on the principle of maximum entropy (Phillips et al., 2006). Among the climatic variables used, isothermality (bio 3) is the one that contributed most to the prediction of Triplochiton scleroxylon habitats in terms of the contribution and importance of permutation. This could be related to the species' ecological requirements in terms of light. Indeed, Triplochiton scleroxylon is a pioneer species that is more frequently found in secondary forests (Akinnagbe et al., 2019). It is therefore demanding in terms of light and its natural seedlings are often very abundant in sufficiently large gaps.

The reduction in predictive power following the permutation of the annual mean precipitation (bio 12) indicates that this variable has also contributed to the discrimination of the species' habitats, but it is not the major factor. Actually, Triplochiton scleroxylon can be found in areas with up to $3000 \mathrm{~mm}$ of rainfall; however, this species is not subordinated to evergreen forest formation.

Under current climatic conditions, the areas unfavourable to the cultivation and conservation of the species are the coastal phytodistricts and the western part of the Plateau phytodistrict. These areas are characterized by a low probability of the species' presence. This situation would be the result of the land cover dynamics observed in these areas. The evolutionary trend in this land cover dynamics is marked by the growth of agglomerations in the Coastal Phytodistrict, while it is much more in favour of crop and fallow mosaics in the Plateau Phytodistrict.
Although projections of the two scenarios by 2055 indicate the presence of more favourable habitats in the Coastal Phytodistrict, population growth and its impacts could be a handicap to the survival of this species in this area.

\section{Conclusion}

This research shows that the spatial pattern of Triplochiton scleroxylon revealed an aggregative distribution between $1 \mathrm{~m}$ and 7 $\mathrm{m}$ distance. But for a distance between 0 and 1 $\mathrm{m}$ and more than $7 \mathrm{~m}$, the spatial pattern revealed a random spatial distribution. The ecological niche modelling of Triplochiton scleroxylon shows that the current and future climatic conditions of the Guineo-Congolese region of Benin remain favourable for the cultivation and conservation of this species. Unfortunately, these protected habitats are occupied by settlements and fields. Measures for the conservation of this species must be developed and implemented by the local stakeholders. These measures must begin by stopping disturbing activities against this species and increase reforestation.

\section{COMPETING INTERESTS}

The author declare that they have no competing interests.

\section{ACKNOWLEDGEMENTS}

This study was partially supported by the Laboratory of Cartography (LaCarto) of the University of Abomey-Calavi (Benin). I'm grateful to the informants and the students who helped in field work.

\section{REFERENCES}

Adedeji GA, Aiyeloja AA, Larinde SL, Omokhua GE. 2014. Effect of Seasons on Colonisation and Suitability of Triplochiton Scleroxylon K. Schum. Wood for Beekeeping in Rivers State, Nigeria. Nat Sci, 12(8):117-122.

Adomou CA. 2005. Vegetation patterns and environmental gradients in Benin: Implications for biogeography and 
conservation. $\mathrm{PhD}$ thesis, Wageningen University, $150 \mathrm{p}$.

Adomou CA, Agbani OP, Sinsin B. 2011. Plantes. In Protection de la nature en Afrique de l'Ouest: Une Liste Rouge pour le Bénin. Nature Conservation in West Africa: Red List for Benin, Neuenschwander P, Sinsin B, Goergen G (eds). International Institute of Tropical Agriculture: Ibadan, Nigeria; 21-46.

Akoegninou A, Van Der Burg WJ, Van Der Maesen LJG. 2006. Flore analytique $d u$ Bénin. Backhuys Publishers, Wageningen, $1034 \mathrm{p}$.

Akinnagbe A, Gailing O, Finkeldey R, Lawal A. 2019. Towards conservation of genetic variation of tropical tree species with differing successional status: the case of Mansonia altissima A. Chev and Triplochiton scleroxylon K. Schum. Tropical Conservation Science, 12: 1-9. DOI: $10.1177 / 1940082919864267$

Allouche O, Tsoar A, Kadmon R. 2006. Assessing the accuracy of species distribution models: prevalence, kappa and the true skill statistic (TSS). Journal of Applied Ecology, 43: 1223-1232. DOI: http://dx.doi.org/10.1111/j.13652664.2006.01214.x

Arouna O. 2012. Cartographie et modélisation prédictive des changements spatiotemporels de la végétation dans la commune de Djidja au Bénin : implications pour l'aménagement du territoire. Thèse de Doctorat, EDP/FLASH, Université d'AbomeyCalavi, Bénin, $161 \mathrm{p}+$ Annexes.

ASECNA (Agence pour la Sécurité de la Navigation Aérienne en Afrique et à Madagascar). 2018. Données climatiques de la station météorologique de Cotonou, Bénin.

Diouf J, Mbaye MS, Camara AA, Dieng B, Diouf N, Sarr M, Noba K. 2019. Structure et dynamique de la flore et la végétation de la réserve spéciale botanique de Noflaye (Sénégal). Int. J. Biol. Chem. Sci., 13(3): 1458-1472.
DOI:

https://dx.doi.org/10.4314/ijbcs.v13i3.20

Dohou OR. 2006. Contribution méthodologique à l'étude de la répartition spatiale des arbres: détermination de l'aire optimale d'étude de la répartition spatiale des arbres dans un peuplement à dominance Isoberlinia spp dans la forêt classée de Wari-Maro (Centre-Bénin). Thèse d'Ingénieur Agronome, FSA/UAC, Abomey-Calavi, Bénin, $93 \mathrm{p}$.

Dungan JL, Perry JN, Dale MRT, Legendre P, Citron-Pousty S, Fortin M-J, Jakomulska A, Miriti M, Rosenberg MS. 2002. A balanced view of scale in spatial statistical analysis. Ecography, 25: 626640.

DOI:

https://doi.org/10.1034/j.1600-

0587.2002.250510.x

Elith J, Kearney M, Phillips S. 2010. The art of modelling range-shifting species. Methods in Ecology and Evolution, 1: 330-342. DOI: $10.1111 / \mathrm{j} .2041-$ 210X.2010.00036.X

Fandohan AB, Oduor AMO, Sode AI, Wu L, Cuni-Sanchez A, Assede E, Gouwakinnou GN. 2015. Modeling vulnerability of protected areas to invasion by Chromolaena odorata under current and future climates. Ecosystem Health and Sustainability, 1(6): 1-12. DOI: http://dx.doi.org/10.1890/EHS150003.1

Folahan SON, Dissou EF, Akouehou GS, Tente AHB, Boko M. 2018. Ecologie et structure des groupements végétaux des écosystèmes de la Lama au Sud-Bénin. Int. J. Biol. Chem. Sci., 12(1) : 322-340. DOI : https://dx.doi.org/10.4314/ijbcs.v12i1.26

GIEC. 2013. Changement climatiques: les éléments scientifiques. Contribution du Groupe de travail I au $5^{\text {ème }}$ rapport d'évaluation du GIEC, 34 p.

Goreaud F. 2000. Apports de l'analyse de la structure spatiale en forêt tempérée à l'étude et la modélisation des peuplements complexes. Thèse de 
doctorat en Sciences Forestières, ENGREF, $362 \mathrm{p}$.

Goussanou AC, Tente AB, Akouehou G, Salako KV, Glele-Kakaï LR, Sinsin AB. 2017. Structural and spatial patterns of Isoberlinia species in a disturbed community forest (Benin, West Africa). Kastamonu Univ., Journal of Forestry Faculty, 17(2): 225-237. DOI: 10.17475/kastorman.340150

INSAE (Institut National des Statistiques et de l'Analyse Economique). 2013. Effectifs de la population des villages et quartiers de villes du Bénin, Cotonou, Bénin, 85 p.

Jesel S. 2005. Ecologie et dynamique de la régénération de Dicorynia guineensis (Caesalpiniaceae) dans la forêt guyannaise. Thèse de Doctorat, INRA, Paris-Grignon, 307 p.

Kamga FT. 2019. Modeling adsorption mechanism of paraquat onto Ayous (Triplochiton scleroxylon) wood sawdust. Applied Water Science, 9(1): 17. DOI: https://doi.org/10.1007/s13201018-0879-3

Karimou S. 2015. Distribution spatiale et dynamique de Khaya senegalensis, Afzelia africana, Pterocarpus erinaceus et Daniellia oliveri des parcours naturels de transhumance du Bassin Supérieur de la Sota au Bénin. Mémoire de DEA, EDP/FLASH/UAC, Abomey-Calavi, Bénin, $75 \mathrm{p}$.

Kiki JM. 2005. Etude de la répartition spatiale des arbres de Isoberlinia spp. dans la forêt classée de Wari-Maro (Centre Benin). Thèse d'Ingénieur Agronome, FSA/UAC, Abomey-Calavi, Bénin, 101 p.

Krawczyk-Szulc P, Wiszniewska M, Pałczyński C, Nowakowska-Świrta E, Kozak A, Walusiak-Skorupa J. 2014. Occupational asthma caused by samba (triplochiton scleroxylon) wood dust in a professional maker of wooden models of airplanes: a case study. International Journal of Occupational Medicine and Environmental Health, 27(3): 512-519.
DOI: http://dx.doi.org/10.2478/s13382014-0253-0

Neuenschwander P, Sinsin B, Goergen G. (eds). 2011. Protection de la nature en Afrique de l'Ouest: Une liste rouge pour le Bénin. International Institute of Tropical Agriculture: Ibadan, Nigeria; 365 p.

Nketiah T, Newton AC, Leakey RRB. 1998. Vegetative propagation of Triplochiton scleroxylon K. Schum in Ghana. Forest Ecology and Management, 105: 99-105.

Oluoti K, Pettersson A, Richards T. 2016. Investigating the morphology and reactivity of chars from Triplochiton scleroxylon pyrolysed under varied conditions. Bioresource Technology, 208: 94-99. DOI: http://dx.doi.org/10.1016/j.biortech.2016 .02 .061

Orekan V, Tente B, Houndagba CJ, Abdoulaye D. 2010. Occupation des Terres et Dynamique du Couvert Végétal. In Atlas de la Biodiversité de l'Afrique de l'Ouest: Bénin (Tome I), Sinsin B, Kampmann D (eds). BIOTA : Cotonou \& Frankfurt / Main; 154-166.

Orwa C, Mutua A, Kindt R, Jamnadass R, Simons A. 2009. Agroforestry Database: a tree reference and selection guide version 4.0 (http://www.worldagroforestry.org/af/tre $\mathrm{edb} /$ )

Phillips SJ, Anderson RP, Schapire RE. 2006. Maximum entropy modeling of species geographic distributions. Ecological Modelling, 190: 231-259. DOI: 10.1016/j.ecolmodel.2005.03.026

Platts PJ, Marchant RA. 2015. AFRICLIM: High-resolution climate projections for ecological applications in Africa. African Journal of Ecology, 53: 103-108. DOI: https://doi.org/10.1111/aje.12180

R Core Team. 2019. R: A Language and Environment for Statistical Computing. R Foundation for Statistical Computing: Vienna, Austria. URL https://www.Rproject.org/. 
Ripley BD. 1977. Modelling spatial patterns. Journal of the Royal Statistical Society, 39: 172-212.

Ripley BD. 1991. Statistical Inference for Spatial Processes. Cambridge University Press : Cambridge, $150 \mathrm{p}$.

Salako KV, Kénou Ch, Dainou K, Assogbadjo EA, Glele-Kakaï LR. 2018. Impacts of land use types on spatial patterns and neighbourhood distance of the agroforestry palm Borassus aethiopum Mart. in two climatic regions in Benin, West Africa. Agroforest Syst, 15 p. DOI : https://doi.org/10.1007/s10457-0180205-y

Stoyan D. 1987. Statistical Analysis of Spatial Point Processes: A Soft-Core Model and Cross-Correlations of Marks. Biometrical Journal, 29(8): 971-980. DOI: $10.1002 /$ bimj.4710290811

Toko Imorou I. 2013. Effets des facteurs abiotiques sur la répartition spatiale des groupements végétaux dans la zone de transition soudano-guinéenne du Bénin. Int. J. Biol. Chem. Sci., 7(6): 2178-2192. DOI: http://dx.doi.org/10.4314/ijbcs.v7i6.1

Toko Imorou I, Arouna O, Houessou GL, Sinsin B. 2017. Contribution of sacred forests to biodiversity conservation: Case of Adjahouto and Lokozoun sacred forests in southern Benin, West Africa. Int. J. Biol. Chem. Sci., 11(6): 29362951.

DOI: https://dx.doi.org/10.4314/ijbcs.v11i6.3.

Toko Imorou I, Arouna O, Zakari S, Djaouga M, Thomas O, Kinmadon G. 2019. Evaluation de la déforestation et de la dégradation des forêts dans les aires protégées et terroirs villageois du bassin cotonnier du Bénin. Conférence OSFACO : Des images satellites pour la gestion durable des territoires en Afrique, Mars 2019, Cotonou, Bénin, 25 pages. hal-02189556

Vidal C, Gonzalez-Quintela A, Rodriguez V, Armisen M, Linares T, FernandezCaldas E. 2006. Anaphylaxis to Cyphomandra betacea Sendth (tamarillo) in an obeche wood (Triplochiton scleroxylon)-allergic patient. Ann Allergy Asthma Immunol., 96: $870-873$.

Vroh BTA, Ouattara D, Kpangui KB. 2014. Disponibilité des espèces végétales spontanées à usage traditionnel dans la localité d'Agbaou, Centre-ouest de la Côte d'Ivoire. Journal of Applied Biosciences, 76: 6386-6396. DOI: http://dx.doi.org/10.4314/jab.v76i1.11. 